\title{
Shynthesis and Characterizations of Calcium Hydroxyapatite Derived from Crabs Shells (Portunus pelagicus) and Its Potency in Safeguard against to Dental Demineralizations
}

\author{
Indah Raya, ${ }^{1}$ Erna Mayasari, ${ }^{1}$ Afdaliah Yahya, ${ }^{1}$ \\ Muhammad Syahrul, ${ }^{1}$ and Andi Ilham Latunra ${ }^{2}$ \\ ${ }^{1}$ Chemistry Department, Faculty of Mathematics and Natural Sciences, Hasanuddin University, Makassar 90245, Indonesia \\ ${ }^{2}$ Biology Department, Faculty of Mathematics and Natural Sciences, Hasanuddin University, Makassar 90245, Indonesia \\ Correspondence should be addressed to Indah Raya; indahraya05@gmail.com
}

Received 22 September 2014; Revised 31 January 2015; Accepted 23 February 2015

Academic Editor: Sean Peel

Copyright ( $) 2015$ Indah Raya et al. This is an open access article distributed under the Creative Commons Attribution License, which permits unrestricted use, distribution, and reproduction in any medium, provided the original work is properly cited.

Crab's shells of Portunus pelagicus species were used as raw materials for synthesis of hydroxyapatite were used for protection against demineralization of teeth. Calcination was conducted to crab's shells of Portunus pelagicus at temperature of $1000^{\circ} \mathrm{C}$ for 5 hours. The results of calcination was reacted with $\left(\mathrm{NH}_{4}\right)_{2} \mathrm{HPO}_{4}$, then dried at $110^{\circ} \mathrm{C}$ for 5 hours. Sintering was conducted to results of precipitated dried with temperature variations $400-1000^{\circ} \mathrm{C}$ for a hour each variation of temperature then characterized by $\mathrm{X}$-ray diffractometer and FTIR in order to obtain the optimum formation temperature of hydroxyapatite is $800^{\circ} \mathrm{C}$. The hydroxyapatite is then tested its effectiveness in protection against tooth demineralization using acetate buffer $\mathrm{pH} 5.0$ with $1 \mathrm{M}$ acetic acid concentration with the addition of hydroxyapatite and time variation of immersion. The results showed that the rate of tooth demineralization in acetate buffer decreased significantly with the provision of hydroxyapatite into a solution where the addition of the magnitude of hydroxyapatite is greater decrease in the rate of tooth demineralization.

\section{Introduction}

Hydroxyapatite biomaterials are materials that are very widely used in several health purposes, including as a source of calcium for the manufacture of toothpaste and as an important material in the formation/bone repair. The chemical properties of hydroxyapatite are bioactive and compatible with the adjacent bone and teeth. Hydroxyapatite is a calcium phosphate ceramic that is totally biocompatible and nontoxic and becomes an integral part of living bone and teeth tissue [1-8]. So it is important that these materials are produced independently. The raw material for the production of hydroxyapatite biomaterial is very easily available and abundant in Indonesia. The production process was easy and the cost is also relatively inexpensive if done on a large scale. Among the abundant raw materials are the shells of crabs, which are one of Indonesia's main export commodities. Export of Crabs commodity by Indonesia amounted to
604.215-625.000 tons/year without the shell form, while domestic consumption is expected to be so much more, as in Makassar, carrying 292.5 tons exported in the form of crab without shell with the main export destination being Singapore [9]. If the mass of crab shells $25-50 \%$ of the total mass, it can be estimated that in 2012 produced the shells of crabs around 151,053.75 to 302,107.5 tons in Indonesia and 73.125 to 146.25 tons in Makassar (a region of Indonesia), there was just from crabs production were exported. This value is of course even more if the crab's consumptions in the country are also taken into account. This suggests the existence of crab shells is abundant in Indonesia, including in Makassar. As known in Indonesia, the shells of crabs have not been used, so it will only be a waste disturbing environment $[7,8]$.

Crabs shells containing calcium carbonate $\left(\mathrm{CaCO}_{3}\right)$ are very abundant; amount $40-70 \%$, varies according to the species [7]. Calcium carbonate can be further processed into 
calcium hydroxyapatite $\left[\mathrm{Ca}_{10}\left(\mathrm{PO}_{4}\right)_{6}(\mathrm{OH})_{2}\right][4,5]$. According to Strassler [10], hydroxyapatite is one of the active ingredient materials that are widely used in toothpaste products for protection against teeth demineralization [11-13].

The crystals structure of hydroxyapatite will be better by using $\mathrm{CaO}$ as a precursor of calcium. However, the use of these compounds also produces carbonate apatite $\left[\mathrm{Ca}_{10}\left(\mathrm{PO}_{4}\right)_{6} \mathrm{CO}_{3}\right]$ in a fairly large percentage. This is because the calcination process cannot completely eliminate carbon dioxide $\left(\mathrm{CO}_{2}\right)$ in $\mathrm{CaCO}_{3}$ so that there can be reaction with the precursor phosphate. However, the carbonate apatite heating at a temperature of $700^{\circ}-900^{\circ} \mathrm{C}$ for $2-5$ hours, followed by washing using distilled water, the carbonate apatite can be hydroxyapatite [11-13]. The instrument were used in this research were glass apparatus, Ohaus analytical balance, petri dish, porcelain cup, Buchner flask, Buchner funnel, vacuum pump Sargent-Welch Co. Model 1400, magnetic stirrer, magnetic bar, hotplate Idealife, $\mathrm{pH}$ meter, Furnace Thermolyse 6000-Barnstead, dessicator, thermometers, Spnisosfd oven, stopwatch, Shimadzu X-ray diffractometer (XRD) Model 6000, X-ray Fluorescence (XRF) Shimadzu, Fourier Transform Infra-Red (FTIR) Prestige-21 Shimadzu, Scanning Electron Microscopy combined with the ability to generate localized chemical information (SEM-EDXA) Variant, and UV-VIS Shimadzu model 6105. This is because the carbonate ion compounds are able to inhibit the crystallization process $\mathrm{Ca}_{10}\left(\mathrm{PO}_{4}\right)_{6}(\mathrm{OH})_{2}$ so that the results will be dominated by an amorphous phase [14].

The calcinations temperatures of $\mathrm{CaCO}_{3}$ range from $900^{\circ}$ to $1200^{\circ} \mathrm{C}$. If the $\mathrm{CaCO}_{3}$ burned at temperature calcinations, decomposition reaction of $\mathrm{CaCO}_{3}$ into $\mathrm{CaO}$ will occur and $\mathrm{CO}_{2}$ emissions are dominant and will be issued as a result of the combustion reaction [13-15].

\section{Experimental}

2.1. Research Materials. The following materials used are as follows. Waste of crabs shells Portunus pelagicus species was taken from an exporter crabs company in industry areal, Makassar city, south Sulawesi province, Indonesia. Tooth samples were taken from Dr. Wahidin hospital, and $\left(\mathrm{NH}_{4}\right)_{2} \mathrm{HPO}_{4}$ was obtained from Fluka chemical, $\mathrm{CH}_{3} \mathrm{COOH}$ glacial $100 \%, \mathrm{CH}_{3} \mathrm{COONa} \cdot 3 \mathrm{H}_{2} \mathrm{O}$ from Merck, $\left(\mathrm{NH}_{4}\right)_{6} \mathrm{Mo}_{7} \mathrm{O}_{24} \cdot 4 \mathrm{H}_{2} \mathrm{O}$ from Aldrich, $\mathrm{NH}_{4} \mathrm{VO}_{3}$ from Aldrich, $\mathrm{HNO}_{3}$ and $\mathrm{NaF}$ from Fluka chem., $\left(\mathrm{NH}_{4}\right)_{2} \mathrm{C}_{2} \mathrm{O}_{4}$, distilled water, aluminum foil, and Whatman filter paper numbers 40 and 42 .

2.2. Research Instruments. The instruments were used in this research that glass as commonly used in laboratories, Ohaus analytical balance, petri dish, porcelain cup, Buchner flask, Buchner funnel, vacuum pump Sargent-Welch Co. Model 1400, magnetic stirrer, magnetic bar, hotplate Idealife, pH meter, Furnace Thermolyse 6000 Barnstead, dessicator, thermometers, oven Spnisosfd, stopwatch, Shimadzu X-ray diffractometer (XRD) Model 6000, X-ray fluorescence (XRF) Shimadzu, Fourier transform infrared (FTIR) Prestige-21 Shimadzu, scanning electron microscopy combined with the ability to generate localized chemical information (SEMEDXA) variant, and UV-VIS Shimadzu model 6105.

\subsection{Synthesis of Hydroxyapatite from Waste Shell Crab Por-} tunus pelagicus. Crabs shells Portunus pelagicus waste was cleaned with distilled water and dried at room temperature. Furthermore, to transform crabs shells into $\mathrm{CaCO}_{3}$ and then into $\mathrm{CaO}$, calcinations were performed on the samples at $1000^{\circ} \mathrm{C}$ temperature for 5 hours at a rate of temperature rise $5^{\circ} \mathrm{C} /$ minute. The containment of calcium (Ca) was determined by using XRF. Calcium oxide $(\mathrm{CaO})$ obtaining dominated as result of calcinations and then made suspensions in $100 \mathrm{~mL}$ of distilled water with a calcium concentration of $0.3 \mathrm{M}$. The suspensions reacted by dropwise with a $100 \mathrm{~mL} 0.2 \mathrm{M}$ of $\left(\mathrm{NH}_{4}\right)_{2} \mathrm{HPO}_{4}$ solution through the coprecipitation method, at temperatures around $40^{\circ} \mathrm{C}$ while the solution was stirred for $2-5$ hours. The precipitation allowed stand overnight or 24 hours at room temperature, and the precipitate is filtered with a Whatman filter paper number 40 and dried at $110^{\circ} \mathrm{C}$ for 5 hours. The pure hydroxyapatite obtained by sintering to the dried precipitate at various temperatures of $500^{\circ}-900^{\circ} \mathrm{C}$ for 4 hours $[16,17]$. The results washed with distilled water and then dried at a temperature of $110^{\circ} \mathrm{C}$. The characterization of the compounds was performed by using X-ray diffraction (XRD), FTIR, and SEM-EDXA.

2.4. The Teeth Demineralization Tested. The proven in vitro demineralization of teeth was conducted through evaluating the concentration of phosphate in solution by using the UVVis spectroscopy. The effectiveness of hydroxyapatite to protection against teeth demineralization was tested in acetate buffer $\mathrm{pH} 5.0$ solutions, with $1 \mathrm{M}$ of acetic acid concentration with the addition of hydroxyapatite in varying concentrations and immersion time [18]. Each of 5 beakers was filled with $300 \mathrm{~mL}$ of acetate buffer $\mathrm{pH} 5.0$ with acetic acid concentration of $1 \mathrm{M}$. An acetate buffer was left without adding anything as a comparison. An acetate buffer was then added $10 \mathrm{ppm}$ of $\mathrm{NaF}$ left without addition of $\mathrm{Ca}_{10}\left(\mathrm{PO}_{4}\right)_{6}(\mathrm{OH})_{2}$. Other three pieces beaker of acetate buffer containing $10 \mathrm{ppm}$ of $\mathrm{NaF}$ are adding of $\mathrm{Ca}_{10}\left(\mathrm{PO}_{4}\right)_{6}(\mathrm{OH})_{2}$ with variation concentration of $25 \mathrm{ppm}, 50 \mathrm{ppm}$, and $100 \mathrm{ppm}$. The cleaned tooth samples were immersed in each of 5 beakers of solutions. The immersed times of tooth samples in solution are 3, 6, 9, 24 , and 48 hours, respectively. Furthermore, the phosphate concentration in each solution was measured by using UVVis spectrophotometer with the wavelength for phosphate ( $\lambda$ maks) being $432 \mathrm{~nm}$.

\section{Results and Discussion}

3.1. Calcinations of Crab Shells. Synthesis $\mathrm{Ca}_{10}\left(\mathrm{PO}_{4}\right)_{6}(\mathrm{OH})_{2}$ begins with a calcinations crab shell at $1000^{\circ} \mathrm{C}$ for 5 hours. The calcinations aim to eliminate the organic component in the shells of crabs and convert $\mathrm{CaCO}_{3}$ compound which is the dominant compound in the shells of crabs into $\mathrm{CaO}$ through the elimination of $\mathrm{CO}_{2}$ in gas form. Characterizing the calcinations results was conducted by X-ray, XRF, and FTIR. The results can be seen from the diffraction pattern of the crab shells before and after calcinations at a temperature of 


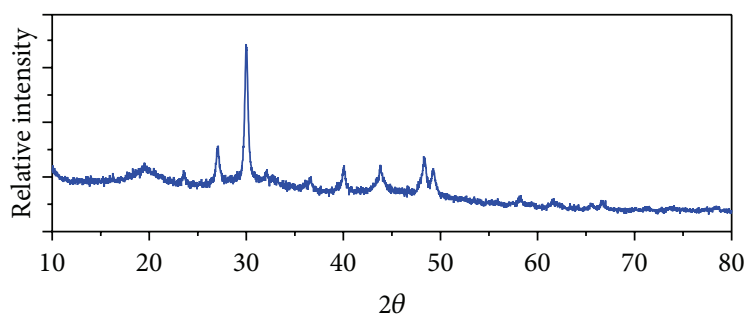

- Before calcination

(a)

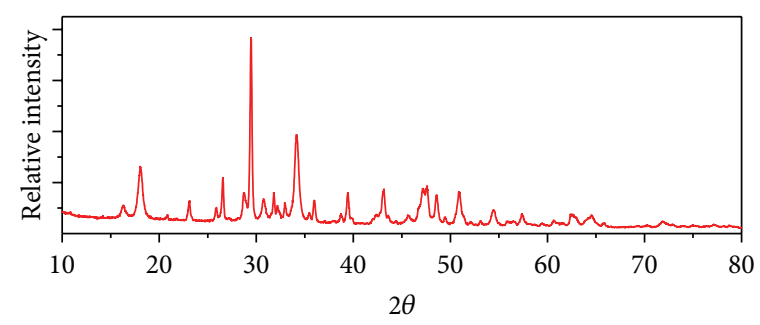

_ After calcination

(b)

Figure 1: Diffractogram of crab shell; (a) before calcinations and (b) after calcinations at temperature $1000^{\circ} \mathrm{C}$ for 5 hours.

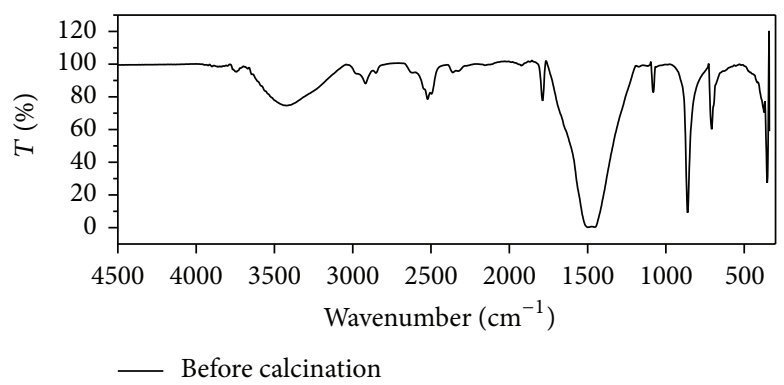

(a)

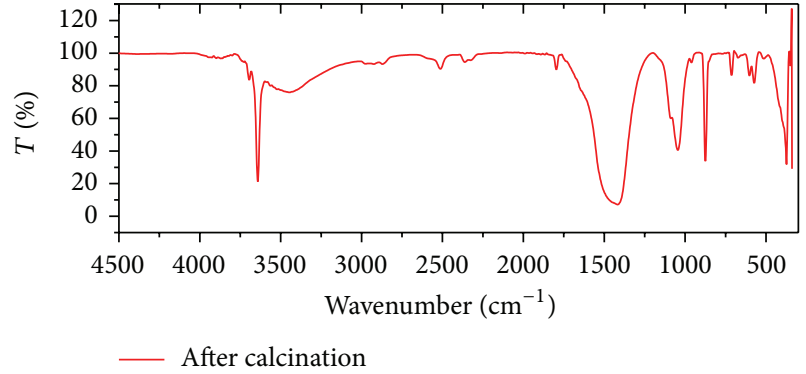

(b)

FIGURE 2: FTIR spectra of crab shells (a) before calcinations and (b) after calcinations at a temperature $1000^{\circ} \mathrm{C}$ for 5 hours.

$1000^{\circ} \mathrm{C}$ for 5 hours (Figure 1). In this figure can be observed changes in the diffraction pattern of crab shells, where the change in the diffraction pattern is due to the chemical change from mixture of $\mathrm{CaCO}_{3}$ with organic matter to pure $\mathrm{CaO}$. The appearance of the sharper peaks in Figure 1 after calcinations (b) is a result of the crystallinity of the $\mathrm{CaO}$.

Identification by FT-IR as shown in Figure 2 showed there is a reduction process of $-\mathrm{CO}_{3}$ groups and some of IR-spectra were missing after calcinations. This shows the elimination of $\mathrm{CO}_{2}$ and organic components occurred [19]. The elimination of $-\mathrm{CO}_{3}$ groups and organic components can also be seen from the data of mass reduction of sample calcinations. Mass reduction during the calcinations process is $56.35 \%$ on average. This means that the efficiency of calcium compounds produced by $43.64 \%$.

The determinations of calcium contained in sample was conducted by using X-ray fluorescence, where obtained calcium is $66.62 \%$ after calcinations. These results are then used to calculate the stoichiometry in determining the number of results calcinations which is needed to react with $\left(\mathrm{NH}_{4}\right)_{2} \mathrm{HPO}_{4}$ as the precursor phosphate.

3.2. Precipitation with Phosphate Precursors. The precipitation reactions aiming to produce $\mathrm{Ca}_{10}\left(\mathrm{PO}_{4}\right)_{6}(\mathrm{OH})_{2}$ used phosphate, $\left(\mathrm{NH}_{4}\right)_{2} \mathrm{HPO}_{4}$, as the precursor and then reacted with $\mathrm{CaO}$ as calcinations results. Side results $\mathrm{Ca}_{10}\left(\mathrm{PO}_{4}\right)_{6} \mathrm{CO}_{3}$ also occur as a product of reaction of $\left(\mathrm{NH}_{4}\right)_{2} \mathrm{HPO}_{4}$ and $\mathrm{CaCO}_{3}$ presence in the calcinations results.

Dried precipitate further sintered on temperature variations of $400^{\circ}-1000^{\circ} \mathrm{C}$ for 2 hours; it is intended to determine the optimum temperature where the $\mathrm{Ca}_{10}\left(\mathrm{PO}_{4}\right)_{6}(\mathrm{OH})_{2}$ is formed, furthermore characterized by using XRD, FT-IR, and SEM-EDXA.

3.3. Characterization of Sintering Results by XRD. XRD Diffractograms of compounds results presented in Figure 3. The diffractograms of each sintering results compounds indicate that the temperature is closely related to the formation of crystals. This is due to the nature of the vibrating atoms moving faster in higher temperatures [19].

The optimum temperature formation of hydroxyapatite was determined by calculation of the probability of the sample phase from the XRD results analysis according to JCPDS standard data, which, JCPDS; $24-0033$ is standard data for $\mathrm{Ca}_{10}\left(\mathrm{PO}_{4}\right)_{6}(\mathrm{OH})_{2} ; 09-0169$ for $\beta-\mathrm{Ca}_{3}\left(\mathrm{PO}_{4}\right)_{2}$; 29-0359 for $\alpha-\mathrm{Ca}_{3}\left(\mathrm{PO}_{4}\right)_{2}, 35-0180 \alpha-\mathrm{Ca}_{3}\left(\mathrm{PO}_{4}\right)_{2} ; 35-0180$ for $\mathrm{Ca}_{10}\left(\mathrm{PO}_{4}\right)_{6} \mathrm{CO}_{3}(\mathrm{OH})_{2}$ and 19-0272 standard data for $\mathrm{Ca}_{10}\left(\mathrm{PO}_{4}\right)_{6} \mathrm{CO}_{3}(\mathrm{OH})_{2}$. Figures 3 and 4 showed that the temperature is closely associated with the formation of hydroxyapatite phase. In the both graphs it can be seen that the maximum intensity of the phase formation of hydroxyapatite has been found by sintering at temperature of $800^{\circ} \mathrm{C}$, it means the optimum temperature of hydroxyapatite formation is $800^{\circ} \mathrm{C}$, and then this result will be used for another application.

The formations of hydroxyapatite phase had been dominated at $800^{\circ} \mathrm{C}$ confirmed by percentage probability sample phase (Figure 5), in which the percentage of hydroxyapatite phase formed around $46.61 \%$, while phases of $\alpha$ $\mathrm{Ca}_{3}\left(\mathrm{PO}_{4}\right)_{2}$ and phase $\beta-\mathrm{Ca}_{3}\left(\mathrm{PO}_{4}\right)_{2}$ are $17.76 \%$ and $19.37 \%$, 


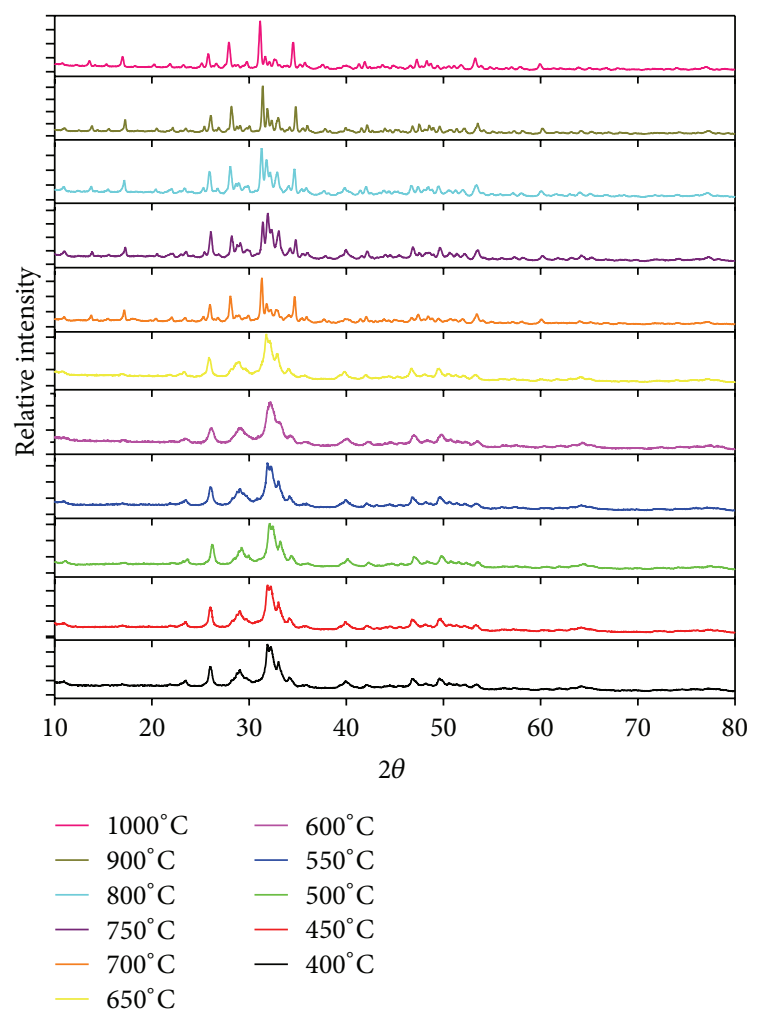

FIGURE 3: Diffraction patterns as a function of temperature sintering of hydroxyapatite.

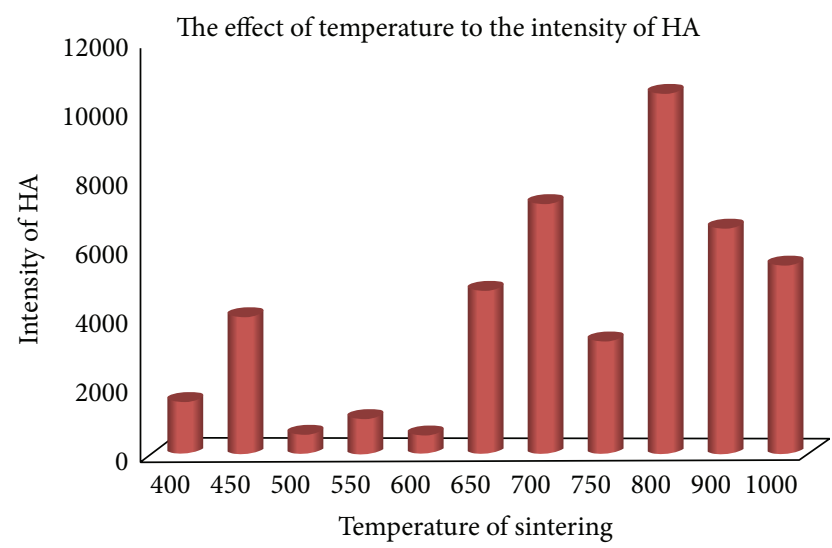

FIGURE 4: The influence of sintering temperatures on the formation of hydroxyapatite phase.

respectively. However, also there is still presence of a phase $\mathrm{Ca}_{10}\left(\mathrm{PO}_{4}\right)_{6} \mathrm{CO}_{3}$ and $\mathrm{Ca}_{10}\left(\mathrm{PO}_{4}\right)_{6} \mathrm{CO}_{3}(\mathrm{OH})_{2}$ with a range of $11.84 \%$ and $4.43 \%$, respectively, which indicates the presence of carbonates. All data coming from the calculations of the XRD spectrum used its software.

The X-ray diffractograms of $\mathrm{Ca}_{10}\left(\mathrm{PO}_{4}\right)_{6}(\mathrm{OH})_{2}$ synthesized at a $800^{\circ} \mathrm{C}$ temperature sintering can be seen in Figure 6, where the peaks of $\mathrm{HA}$ are symbolized by the peak of the crystal $\mathrm{Ca}_{10}\left(\mathrm{PO}_{4}\right)_{6}(\mathrm{OH})_{2}$, while peak $\alpha$-TKF is symbolized crystalline peaks of $\alpha-\mathrm{Ca}_{3}\left(\mathrm{PO}_{4}\right)_{2}$, the symbol $\beta$ TKF for crystalline $\beta-\mathrm{Ca}_{3}\left(\mathrm{PO}_{4}\right)_{2}$, AKA for $\mathrm{Ca}_{10}\left(\mathrm{PO}_{4}\right)_{6} \mathrm{CO}_{3}$,

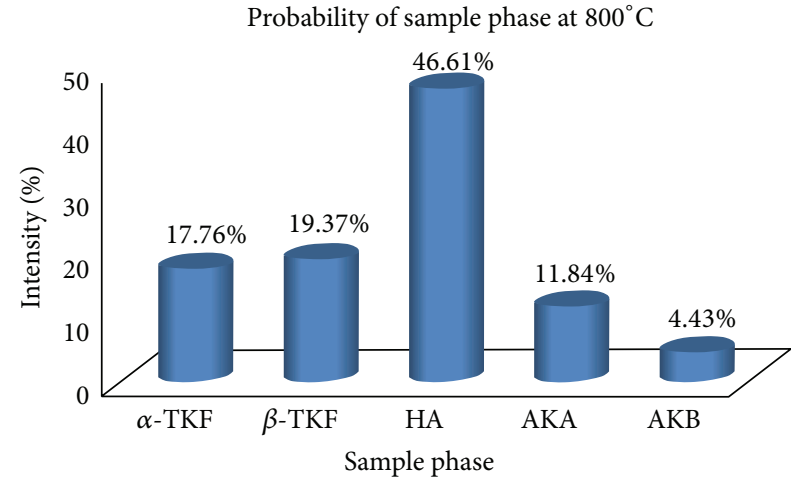

Figure 5: Percentage probability sample phase sintering at a temperature $800^{\circ} \mathrm{C}$, where $\mathrm{HA}=\mathrm{Ca}_{10}\left(\mathrm{PO}_{4}\right)_{6}(\mathrm{OH})_{2}, \alpha$-TKF $=\alpha$ $\mathrm{Ca}_{3}\left(\mathrm{PO}_{4}\right)_{2}, \beta-\mathrm{TKF}=\beta \mathrm{Ca}_{3}\left(\mathrm{PO}_{4}\right)_{2}, \mathrm{AKA}=\mathrm{Ca}_{10}\left(\mathrm{PO}_{4}\right)_{6} \mathrm{CO}_{3}$ and $\mathrm{AKB}$ $=\mathrm{Ca}_{10}\left(\mathrm{PO}_{4}\right)_{6} \mathrm{CO}_{3}(\mathrm{OH})_{2}$.

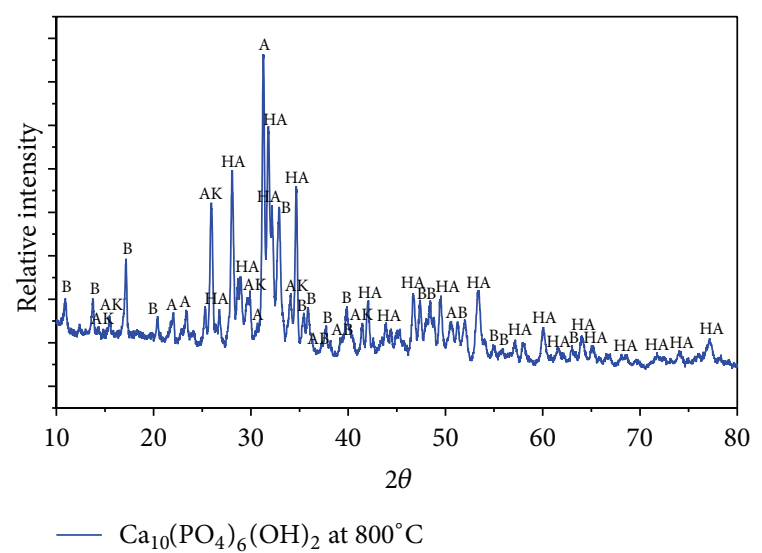

FIGURE 6: Diffractogram of sample were sintered at $800^{\circ} \mathrm{C}$, where, $\mathrm{HA}=\mathrm{Ca}_{10}\left(\mathrm{PO}_{4}\right)_{6}(\mathrm{OH})_{2}, \mathrm{~A}=\alpha-\mathrm{TKF}=\alpha-\mathrm{Ca}_{3}\left(\mathrm{PO}_{4}\right)_{2}, \mathrm{~B}=\beta-\mathrm{TKF}$ $=\beta \mathrm{Ca}_{3}\left(\mathrm{PO}_{4}\right)_{2}, \mathrm{AK}=\mathrm{AKA}=\mathrm{Ca}_{10}\left(\mathrm{PO}_{4}\right)_{6} \mathrm{CO}_{3}$ and $\mathrm{AB}=\mathrm{AKB}=$ $\mathrm{Ca}_{10}\left(\mathrm{PO}_{4}\right)_{6} \mathrm{CO}_{3}(\mathrm{OH})_{2}$.

and $\mathrm{AKB}$ for $\mathrm{Ca}_{10}\left(\mathrm{PO}_{4}\right)_{6} \mathrm{CO}_{3}(\mathrm{OH})_{2}$. The highest intensity peak at $31.2572 \mathrm{deg}$ corresponding to crystalline $\alpha-\mathrm{Ca}_{3}\left(\mathrm{PO}_{4}\right)_{2}$ is seen, the second highest peak intensity is 31.7783 , and the third highest peak intensity is 28.0565 crystals suitable for $\mathrm{Ca}_{10}\left(\mathrm{PO}_{4}\right)_{6}(\mathrm{OH})_{2}$.

3.4. Characterization of Ca-Hydroxyapatite with FT-IR. FTIR results showed that the sintering temperature variation affects the absorption band shapes which generally all sintering results showed absorption band of $-\mathrm{OH}$, absorption band $v 1, v 2, v 3$, and $v 4$ of $\mathrm{PO}_{4}{ }^{3-}$, and $\mathrm{CO}_{3}{ }^{2-}$ groups. Infrared spectra in Figure 7 show the -OH groups at $633 \mathrm{~cm}^{-1}$ which are characteristic of hydroxyapatite [17] appearing on the sintering temperatures of $400-1000^{\circ} \mathrm{C}$. Additionally spectrum also showed higher sintering temperature causing the sharper peaks phosphate group $\left(\mathrm{PO}_{4}^{3-}\right)$ because the nature of the vibrating atoms moves faster at higher temperatures [19]. The presence of the phosphate group indicates the formation of hydroxyapatite in the precipitates. 


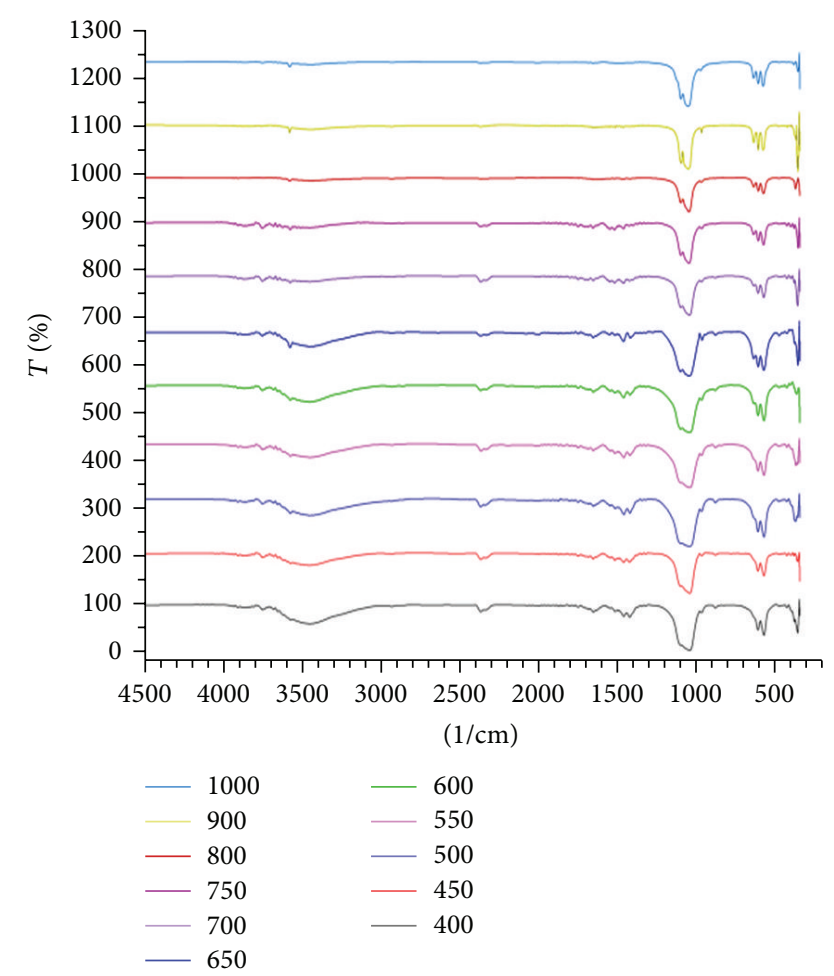

FIGURE 7: FT-IR spectra of synthesis results in various temperatures $\left(400-1000^{\circ} \mathrm{C}\right)$.

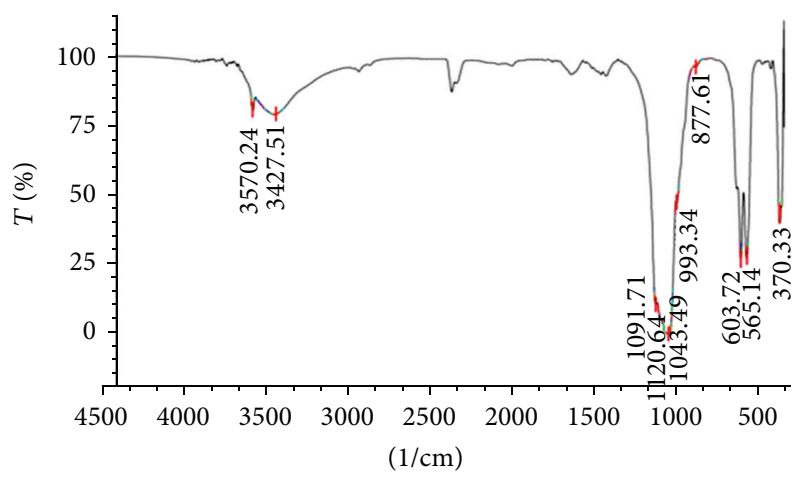

FIGURE 8: FT-IR spectra of hydroxyapatite (HA) were sintered at $800^{\circ} \mathrm{C}$.

The FT-IR spectra of sample were sintered at a temperature of $800^{\circ} \mathrm{C}$ (Figure 8) showing that hydroxyapatite is the dominant compound formed. The stretching frequencies of $\mathrm{PO}_{4}$ group are indicated by $1120.64 \mathrm{~cm}^{-1}$, $1091.71 \mathrm{~cm}^{-1}, 1043.49 \mathrm{~cm}^{-1}$ (v3), $993.34 \mathrm{~cm}^{-1}, 877.61 \mathrm{~cm}^{-1}$ $(v 1), 603.72 \mathrm{~cm}^{-1}, 565.14 \mathrm{~cm}^{-1},(v 4)$, and $370.33 \mathrm{~cm}^{-1}\left(v_{2}\right)$. And a sharp spectrum in the area of $3570.24 \mathrm{~cm}^{-1}$ indicates the presence of free $-\mathrm{OH}$ and $3427.51 \mathrm{~cm}^{-1}$ indicating $\mathrm{OH}$ bounded, and this is indicating that the dominant compound is $\mathrm{Ca}_{10}\left(\mathrm{PO}_{4}\right)_{6}(\mathrm{OH})_{2}$. While area of $1654.92 \mathrm{~cm}^{-1}$, $1458.18 \mathrm{~cm}^{-1}$, and $1421.54 \mathrm{~cm}^{-1}$ indicates the presence of carbonate groups $\left(\mathrm{CO}_{3}{ }^{-}\right)$it can be identified as $\mathrm{Ca}_{10}\left(\mathrm{PO}_{4}\right)_{6} \mathrm{CO}_{3}$

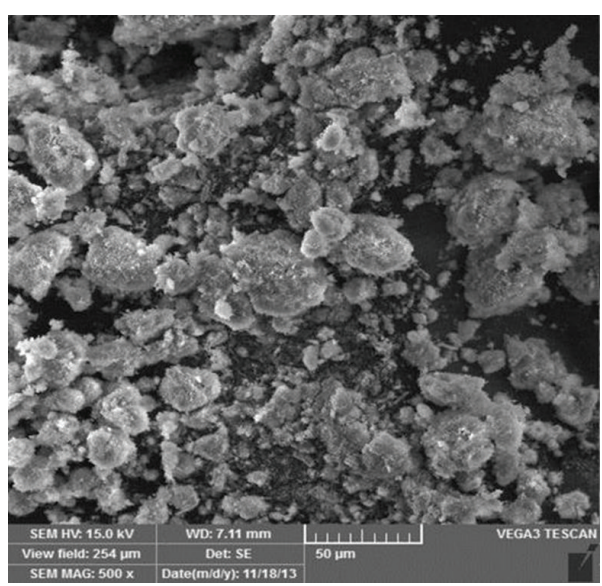

(a)

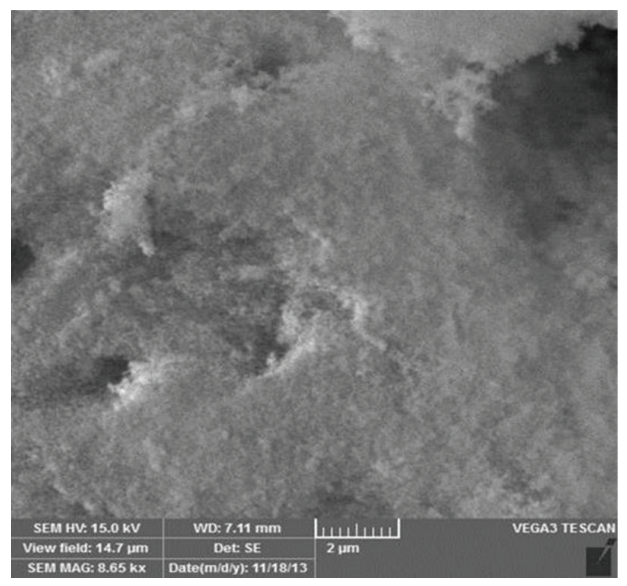

(b)

FIGURE 9: The SEM graph of hydroxyapatite (HA) synthesis from crab shells.

and $\mathrm{Ca}_{10}\left(\mathrm{PO}_{4}\right)_{6} \mathrm{CO}_{3}(\mathrm{OH})_{2}$ which has not been transformed into $\mathrm{Ca}_{10}\left(\mathrm{PO}_{4}\right)_{6}(\mathrm{OH})_{2}$ during the sintering process.

3.5. Characterization of Ca-Hydroxyapatite Sintered at $800^{\circ} \mathrm{C}$ with SEM-EDXA. The results of characterization by SEMEDXA shown in Figure 9(a) show that the size of hydroxyapatite formed from the synthesis tends to be small and only a few are large. While Figure 9(b) shows that the surface of hydroxyapatite is smooth and nonporous, this shows that hydroxyapatite which has synthesis from crab shells can function well as inhibiting tooth demineralization [13].

While in Figure 10 the EDXA spectrum shows the composition of the synthesis yield was dominated by oxygen $(\mathrm{O})$ up to $59.52 \%$, calcium (Ca) up to $23.76 \%$, and phosphorus (P) up to $13.32 \%$. The composition confirmed the composition of hydroxyapatite. It can be concluded that the synthesis results can be achieved to target.

3.6. Inhibition of Tooth: The Demineralization by Presence of $\mathrm{Ca}_{10}\left(\mathrm{PO}_{4}\right)_{6}(\mathrm{OH})_{2}$. Demineralization of teeth is a process of decomposition of the crystal of $\mathrm{Ca}_{10}\left(\mathrm{PO}_{4}\right)_{6}(\mathrm{OH})_{2}$ due 
TABLE 1: Percentage teeth mass remaining on immersion in acetate buffer solution with a certain variation of the treatment for 48 hours.

\begin{tabular}{|c|c|c|c|c|c|}
\hline Number & & Code sample & Initial mass (gram) & Final mass (gram) & Percentage (\%) \\
\hline \multirow{4}{*}{1} & \multirow{4}{*}{$\mathrm{TP}$} & G 1 & 1,54 & 1,52 & 98,21 \\
\hline & & G 2 & 1,07 & 1,04 & 97,81 \\
\hline & & G 3 & 1,73 & 1,69 & 97,55 \\
\hline & & Total & & & 97,86 \\
\hline \multirow{4}{*}{2} & \multirow{4}{*}{$\mathrm{P}$} & G 1 & 0,79 & 0,77 & 96,96 \\
\hline & & G 2 & 0,82 & 0,79 & 96,85 \\
\hline & & G 3 & 1,17 & 1,15 & 97,99 \\
\hline & & Total & & & 97,27 \\
\hline \multirow{4}{*}{3} & \multirow{4}{*}{25} & G 1 & 1,97 & 1,92 & 97,74 \\
\hline & & G 2 & 1,23 & 1,21 & 98,84 \\
\hline & & G 3 & 1,65 & 1,62 & 97,81 \\
\hline & & Total & & & 98,13 \\
\hline \multirow{4}{*}{4} & \multirow{4}{*}{50} & G 1 & 0,91 & 0,89 & 98,33 \\
\hline & & G 2 & 1,20 & 1,18 & 98,01 \\
\hline & & G 3 & 1,26 & 1,24 & 98,10 \\
\hline & & Total & & & 98,15 \\
\hline \multirow{4}{*}{5} & \multirow{4}{*}{100} & G 1 & 1,4589 & 1,44 & 98,70 \\
\hline & & G 2 & 1,053 & 1,0307 & 97,88 \\
\hline & & G 3 & 1,4709 & 1,4448 & 98,22 \\
\hline & & Total & & & 98,27 \\
\hline
\end{tabular}

$\mathrm{G}=$ teeth.

$\mathrm{TP}=$ acetate buffer without the addition of any $\mathrm{NaF}$ and $\mathrm{Ca}_{10}\left(\mathrm{PO}_{4}\right)_{6}(\mathrm{OH})_{2}$.

$\mathrm{P}=$ acetate buffer with only the addition of $\mathrm{NaF}$.

$25=$ acetate buffer addition of $\mathrm{NaF}$ and $25 \mathrm{ppm}$ of $\mathrm{Ca}_{10}\left(\mathrm{PO}_{4}\right)_{6}(\mathrm{OH})_{2}$.

$50=$ acetate buffer addition of $\mathrm{NaF}$ and $50 \mathrm{ppm}$ of $\mathrm{Ca}_{10}\left(\mathrm{PO}_{4}\right)_{6}(\mathrm{OH})_{2}$.

$100=$ acetate buffer addition of $\mathrm{NaF}$ and $100 \mathrm{ppm}$ of $\mathrm{Ca}_{10}\left(\mathrm{PO}_{4}\right)_{6}(\mathrm{OH})_{2}$.

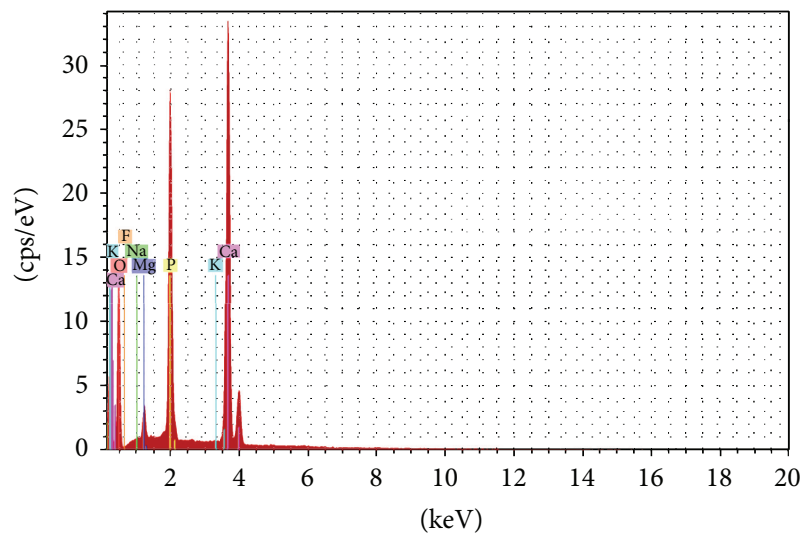

FIGURE 10: The EDXA spectrum of hydroxyapatite (HA) synthesis from crab shells.

to the acidic conditions by releasing $\mathrm{Ca}^{2+}$ and $\mathrm{PO}_{4}{ }^{3-}$ ions. Demineralization of tooth causing increased levels of $\mathrm{Ca}^{2+}$ and $\mathrm{PO}_{4}{ }^{3-}$ in saliva in direct contact with the tooth. In vitro, the rate of tooth demineralization can be observed through the concentrations of $\mathrm{Ca}^{2+}$ and $\mathrm{PO}_{4}{ }^{3-}$ ions in solutions where the tooth was soaked each unit of time. Therefore, increase of $\mathrm{PO}_{4}{ }^{3-}$ ions concentrations in solution a soaked gear can be one of indicators to measure the rate of tooth demineralization.

Figure 11 shows the relationship between the soaking time of teeth versus the increase of the ion $\mathrm{PO}_{4}{ }^{3-}$ levels in solution where the tooth was soaked as well; it appears that with the increasing addition of $\mathrm{Ca}_{10}\left(\mathrm{PO}_{4}\right)_{6}(\mathrm{OH})_{2}$ into the acetate buffer equals to the rate of demineralization decrease. It is can be altered by the amount of $\mathrm{PO}_{4}{ }^{3-}$ ions in solutions; however the addition of $\mathrm{Ca}_{10}\left(\mathrm{PO}_{4}\right)_{6}(\mathrm{OH})_{2}$ ions showed lower amount of $\mathrm{PO}_{4}{ }^{3-}$ ions compared to solutions without the addition of $\mathrm{Ca}_{10}\left(\mathrm{PO}_{4}\right)_{6}(\mathrm{OH})_{2}$. This proves that the $\mathrm{Ca}_{10}\left(\mathrm{PO}_{4}\right)_{6}(\mathrm{OH})_{2}$ were synthesized from the crab shell effective for protection against tooth demineralization.

The decrease in the rate of tooth demineralization with the addition of $\mathrm{Ca}_{10}\left(\mathrm{PO}_{4}\right)_{6}(\mathrm{OH})_{2}$ can also be observed through analyzing the tooth mass reduction in the fifth variation of acetate buffer solution as shown in Table 1. The greater concentrations of $\mathrm{Ca}_{10}\left(\mathrm{PO}_{4}\right)_{6}(\mathrm{OH})_{2}$ in the acetate buffer solution were teeth immersed exhibit the smaller mass of teeth in the solution [19].

Table 1 shows the relationship between tooth mass and the addition of hydroxyapatite.

\section{Conclusion}

Based on these results it is concluded as follows. 


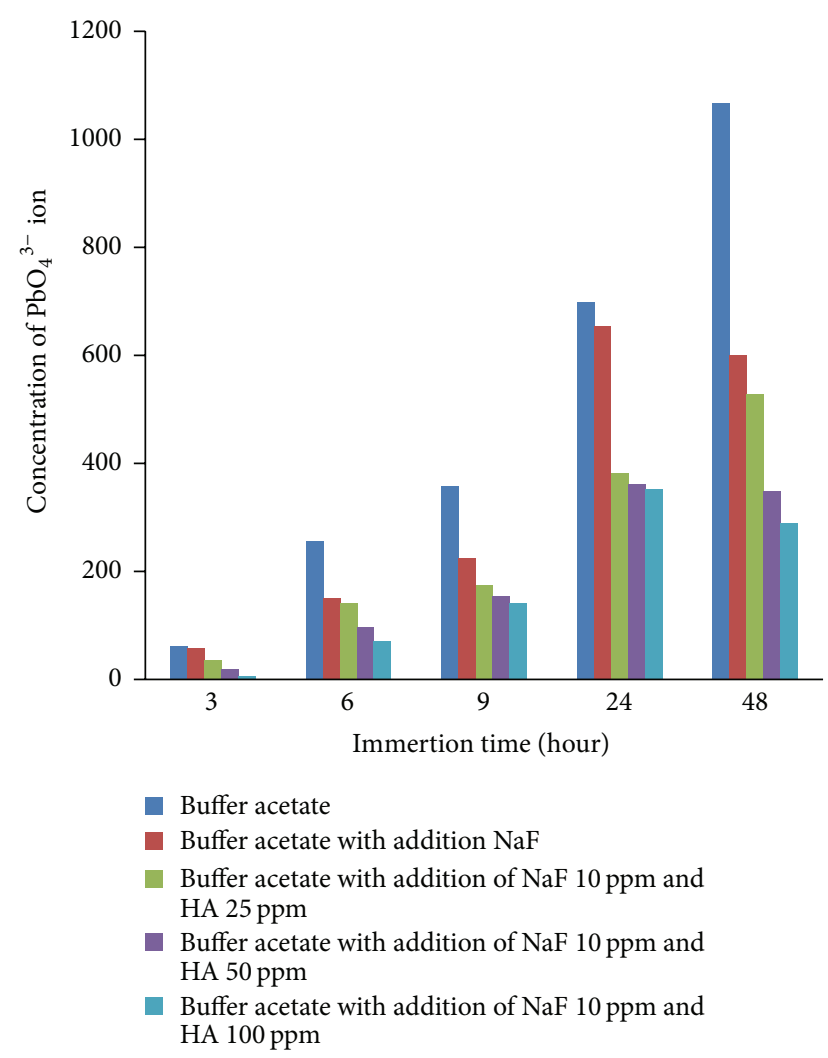

FIGURE 11: Relationship between teeth immersion time versus $\mathrm{PO}_{4}{ }^{3-}$ ion concentration in a solution where teeth soaked or immersed.

(1) Waste of shells crabs (Portunus pelagicus) proved to be used as raw material for the synthesis of $\mathrm{Ca}_{10}\left(\mathrm{PO}_{4}\right)_{6}(\mathrm{OH})_{2}$ due to high calcium levels which amounted to $66.62 \%$ in addition to the abundant existence as waste.

(2) The optimum temperature formation of $\mathrm{Ca}_{10}\left(\mathrm{PO}_{4}\right)_{6}(\mathrm{OH})_{2}$ is at $800^{\circ} \mathrm{C}$.

(3) $\mathrm{Ca}_{10}\left(\mathrm{PO}_{4}\right)_{6}(\mathrm{OH})_{2}$ were synthesized from waste of shell crabs (Portunus pelagicus) in vitro effectively inhibiting the rate of demineralization of the tooth where the greater the addition of $\mathrm{Ca}_{10}\left(\mathrm{PO}_{4}\right)_{6}(\mathrm{OH})_{2}$ in the solution, the more the inhibiting demineralization of the tooth or the smaller the rate of tooth demineralization in solution.

\section{Conflict of Interests}

The authors declare that there is no conflict of interests regarding the publication of this paper.

\section{Acknowledgments}

The authors gratefully acknowledge the Director General of Higher Education that has funded this research through a MP3EI grant in 2013 and 2014. Thanks are also conveyed to Dr. Dahlang (Department of Physics, FMIPA-UNHAS) which has measured XRF and XRD. Similarly the authors thank the UNM Materials Physics Laboratory that has measured XRD and SEM-EDXA and also pronounced thanks to Dr. Kartini (Integrated Chemistry Laboratory UNHAS) who has helped measurement of FTIR and UV-Vis.

\section{References}

[1] J. S. Wefel and M. W. J. Dodds, Oral Biologic and the Demineralization and Remineralization of Teeth, Appleton \& Lange, Stamford, Conn, USA, 1999.

[2] M. Jarcho, "Biomaterial aspects of calcium phosphates. Properties and applications," Dental Clinics of North America, vol. 30, no. 1, pp. 25-47, 1986.

[3] G. L. de Lange, C. de Putter, and F. L. J. de Wijs, "Histological and ultrastructural appearance of the hydroxyapatite-bone interface," Journal of Biomedical Materials Research, vol. 24, no. 7, pp. 829-845, 1990.

[4] B. M. Tracy and R. H. Doremus, "Direct electron microscopy studies of the bone-hydroxylapatite interface," Journal of Biomedical Materials Research, vol. 18, no. 7, pp. 719-726, 1984.

[5] D. E. Steflik, R. V. McKinney Jr., and D. L. Koth, "Epithelial attachment to ceramic dental implants," Annals of the New York Academy of Sciences, vol. 523, pp. 4-18, 1988.

[6] K. Donath and G. A. Breuner, "A method for the study of undecalcified bones and teeth with attached soft tissues. The Säge-Schliff (sawing and grinding) technique," Journal of Oral Pathology, vol. 11, no. 4, pp. 318-326, 1982.

[7] P.-I. Brånemark, G. A. Zarb, and T. Albrektsson, TissueIntegrated Prostheses: Osseointegration in Clinical Dentistry, Quintessence Publishing, Chicago, Ill, USA, 1985.

[8] L. Linder, "High-resolution microscopy of the implant-tissue interface," Acta Orthopaedica Scandinavica, vol. 56, no. 3, pp. 269-272, 1985.

[9] BPS, Data Hasil Ekspor Kepiting pada Tahun 2011, BPS, 2012, http://sulsel.bps.go.id/archives/49867.

[10] Harianingsih, Pemanfaatan limbah cangkang kepiting menjadi kitosan sebagai Bahan Pelapis (Coater) pada Buah Stroberi [M.S. thesis], Diponegoro University, Semarang, Indonesia, 2010.

[11] S. U. Dewi, Pembuatan Komposit Kalsium Fosfat-Kitosan dengan Metode Sonikasi [thesis], Post Graduate Program of Bogor Agricultural University, Bogor, Indonesia, 2009.

[12] H. E. Strassler, Toothpaste Ingredients, 2011, http://d3e9u3gw8odyw8.cloudfront.net/toothpaste_ingredients.pdf.

[13] E. Fujii, K. Kawabata, Y. Nakazaki et al., "Fabrication of hydroxyapatite with controlled morphology in a micro-reactor," Journal of the Ceramic Society of Japan, vol. 119, no. 1386, pp. 116$119,2011$.

[14] S. Ramkumar, W. Wang, S. Li et al., "Carbonation-Calcination Reactions (CCR) Process for High Temperature $\mathrm{CO}_{2}$ and Sulfur Removal," 2011, http://www.rsc.org/suppdata/jm/b9/b925776d/ b925776d.pdf.

[15] F. Zulti, Spektroskopi Inframerah, Serapan Atomik, Serapan Sinar Tampak dan Ultraviolet Hidroksiapatit dari Cangkang telur [Ph.D. thesis], Department of Physics, Faculty of Mathematics and Natural Sciences, Institute of Agriculture Bogor, Bogor, Indonesia, 2008.

[16] R. Samsiah, Karakterisasi Biokomposit Apatit-Kitosan dengan XRD (X-Ray Diffraction), FTIR (Fourier Transform Infrared), SEM (Scanning Electron Microscopy) dan Uji Mekanik [M.S. thesis], Department of Physics, Faculty of Mathematics and Natural Sciences, Institute of Agriculture Bogor, Bogor, Indonesia, 2009. 
[17] E. C. Reynolds, "Anticariogenic of amorphous calcium phosphate complexes stabilized by casein phosphopeptide," U.S. Dentistry, vol. 8, pp. 51-54, 1998.

[18] R. L. Karlinsey, A. C. Mackey, T. J. Walker et al., "In vitro remineralization of human and bovine white-spot enamel lesions by NaF dentifrices: a pilot study," Journal of Dentistry and Oral Hygiene, vol. 3, no. 2, pp. 22-29, 2011.

[19] JOMI on CD-ROM, 1993 Jan (69-74): Bone Reactions to Hydroxyapatite-Coated Dental, Quinte, 1993. 

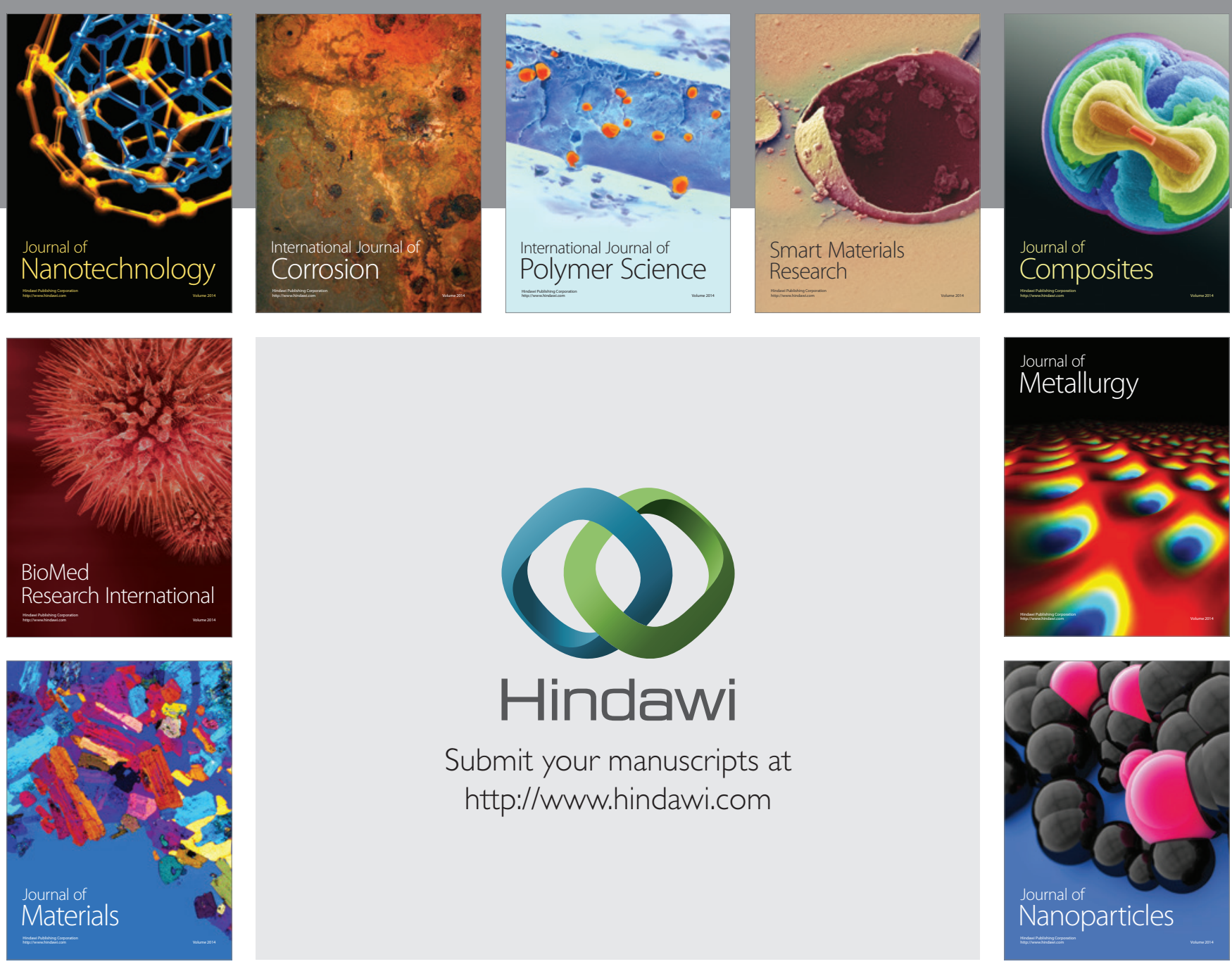

Submit your manuscripts at http://www.hindawi.com
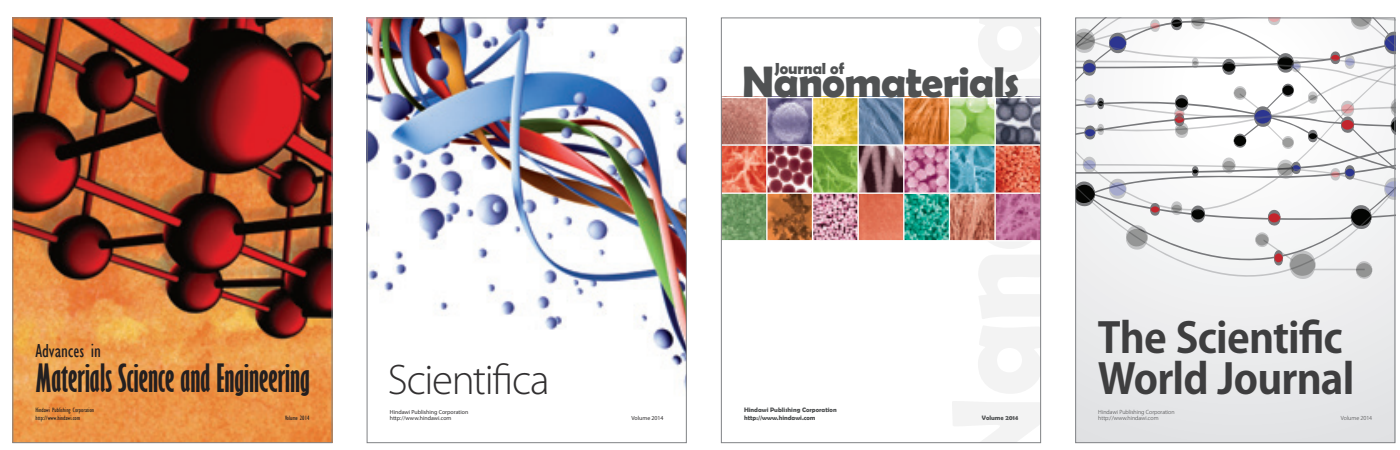

\section{The Scientific World Journal}
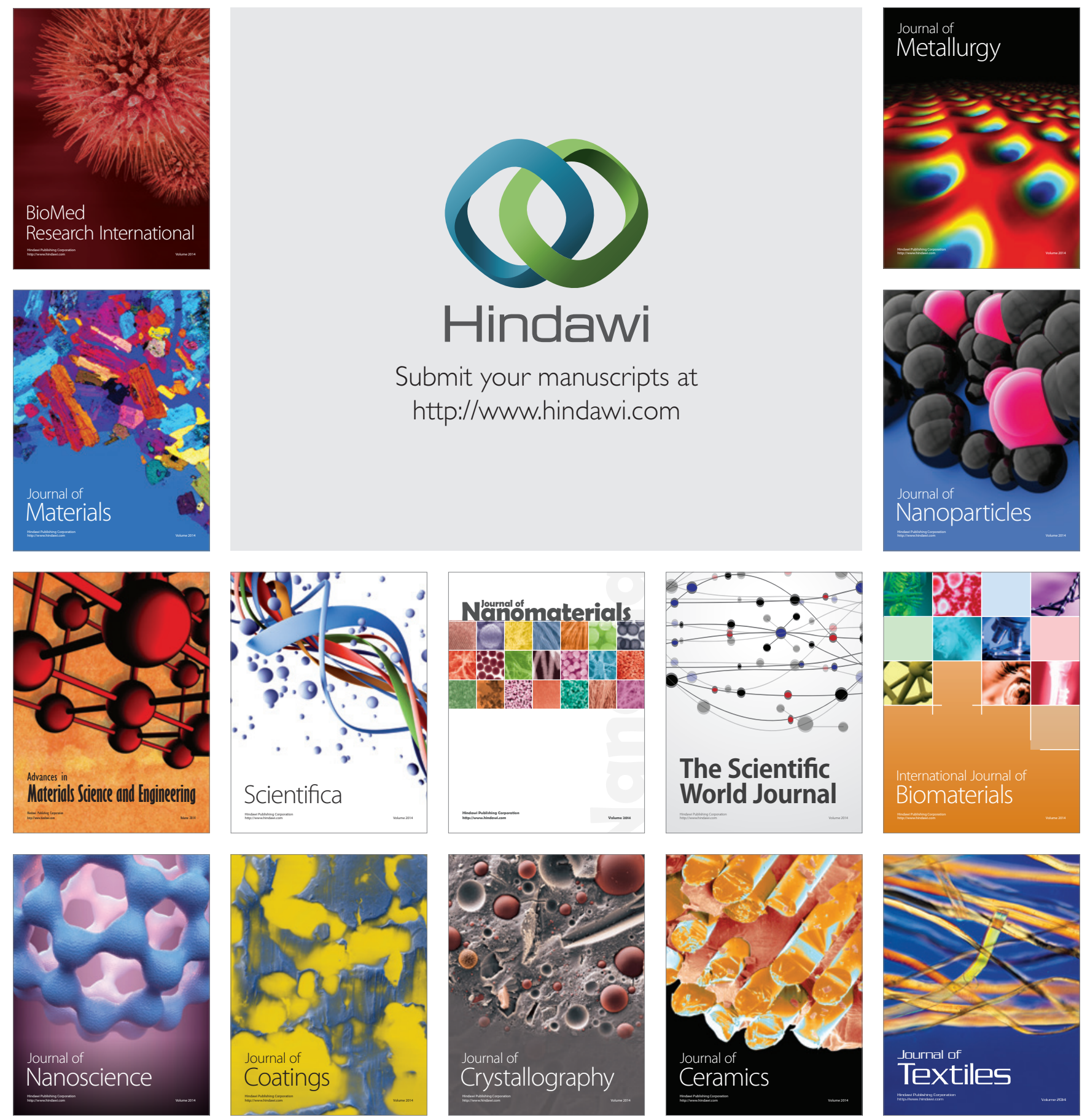